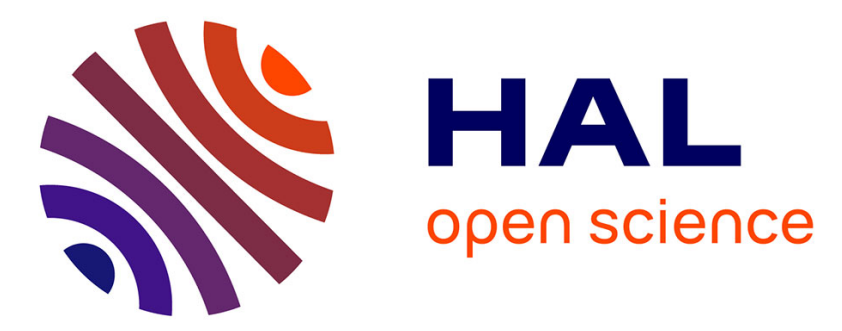

\title{
Barrier heights on cadmium telluride schottky solar cells
} J.P. Ponpon, P. Siffert

\section{To cite this version:}

J.P. Ponpon, P. Siffert. Barrier heights on cadmium telluride schottky solar cells. Revue de Physique Appliquée, 1977, 12 (2), pp.427-430. 10.1051/rphysap:01977001202042700 . jpa-00244192

\section{HAL Id: jpa-00244192 https://hal.science/jpa-00244192}

Submitted on 1 Jan 1977

HAL is a multi-disciplinary open access archive for the deposit and dissemination of scientific research documents, whether they are published or not. The documents may come from teaching and research institutions in France or abroad, or from public or private research centers.
L'archive ouverte pluridisciplinaire HAL, est destinée au dépôt et à la diffusion de documents scientifiques de niveau recherche, publiés ou non, émanant des établissements d'enseignement et de recherche français ou étrangers, des laboratoires publics ou privés. 


\title{
BARRIER HEIGHTS ON CADMIUM TELLURIDE SCHOTTKY SOLAR CELLS
}

\author{
J. P. PONPON and P. SIFFERT \\ Centre de Recherches Nucléaires, Laboratoire de Physique des Rayonnements \\ et d'Electronique Nucléaire, 67037 Strasbourg Cedex, France
}

\begin{abstract}
Résumé. - On a étudié des diodes Schottky sur le tellurure de cadmium de type N. On a montré qu'il existait une relation linéaire entre le travail d'extraction du métal et la hauteur de barrière lorsque cette dernière est mesurée par effet photoélectrique ou à partir des caractéristiques directes des diodes. Des hauteurs de barrière de $0,90 \mathrm{eV}$ ont été atteintes dans le cas de contacts Pt-CdTe. Dans ce cas, les tensions en circuit ouvert des cellules photovoltaïques pouvaient atteindre $680 \mathrm{mV}$ sous éclairement solaire. L'étude du contact $\mathrm{Au}-\mathrm{CdTe}$, effectuée sous vide, immédiatement après le dépôt du métal, a montré que la barrière était immédiatement formée. Néanmoins, lorsque la diode est mise au contact de l'air, la tension en circuit ouvert s'accroît par suite d'une augmentation du facteur $n$.
\end{abstract}

\begin{abstract}
Schottky barriers on N-type cadmium telluride have been studied in view of application to solar cells. The barrier heights, as determined by the photoresponse and forward current measurements show a linear dependence upon the metal work function. Barrier heights up to $0.90 \mathrm{eV}$ have been reached for Pt-CdTe contacts. Open circuit voltages up to $680 \mathrm{mV}$ have been measured for such cells. Investigation of the Au-CdTe barrier immediately after the deposition of the metal (no contact with air) has shown that the barrier is formed immediately under vacuum. However, when the device is brought in contact with air, the open circuit voltage increases due to an increase of the $n$ factor.
\end{abstract}

1. Introduction. - It is well known that cadmium telluride is one of the most attractive material for the realization of thin film solar cells. Then the problem of contacts on such a polycristalline material has to be solved. One approach, which is interesting not only in view of applications to solar cells, but also from a more fundamental point of view, could be the use of Schottky barriers. Up to now, rather little work has been devoted to the study of Schottky barriers on cadmium telluride. However, since the first paper of Mead and Spitzer [1], great improvements in $\mathrm{CdTe}$ crystal growth have been achieved mainly in view of applications to nuclear detectors. Barrier height values for various metals deposited both on $\mathrm{N}$ and $\mathrm{P}$ type crystals have been published [2-3] but large discrepancies in the results occured, probably due to the different surface treatments used (cleaning, polishing or etching).

In this paper we have investigated the barrier heights of various metals deposited on etched $\mathrm{N}$ type cadmium telluride. Further, these barrier heights have been correlated to the open circuit voltage delivered by the final devices.

2. Experimental. - The samples we used were grown by a zone melting technique previously publishhed [4]. They were $N$ type, $200 \Omega . \mathrm{cm}$ in resistivity. After slicing and lapping the crystals were cleaned by conventional techniques. Ohmic contacts were obtained by indium alloy at $350^{\circ} \mathrm{C}$ under argon stream. Prior to the metal deposition the samples were etched in a bromine-methanol solution and finally rinsed in methanol. Metallic films of about $100 \AA$ were deposited at a rate of about $1 \AA / \mathrm{s}$. Barrier heights were determined after removing the samples from the vacuum system both by photoresponse and forward current measurements. The open circuit voltage $V_{\text {oc }}$ was measured under tungsten lamp illumination $\left(100 \mathrm{~mW} / \mathrm{cm}^{2}\right.$, $T=2900 \mathrm{~K})$. Further, for a few samples, photovoltage has been measured immediately after metal deposition, the contacts being taken while the samples were kept all the time under vacuum.

3. Results. - The barrier height values of various metals (In, Pb, Al, Sb, Fe, Ag, Bi, Cu, Ni, Au, Pd, Pt) as determined by photoresponse $\left[\varphi_{\mathrm{B}_{n}}(P)\right]$ and forward current measurement $\left[\varphi_{\mathrm{B} n}(C)\right]$ are reported on table I.

\section{TABLE I}

$\begin{array}{cccc}\text { Metal } & \varphi_{\mathrm{m}}(V) & \varphi_{\mathrm{B} n}(P)(\mathrm{eV}) & \varphi_{\mathrm{B} n}(C)(\mathrm{eV}) \\ \overline{\mathrm{In}} & 3.80 & 0.69 & 0.79 \\ \mathrm{~Pb} & 4.00 & 0.68 & 0.77 \\ \mathrm{Al} & 4.19 & 0.74 & 0.83 \\ \mathrm{Sb} & 4.20 & 0.76 & 0.85 \\ \mathrm{Fe} & 4.28 & 0.78 & 0.85 \\ \mathrm{Ag} & 4.40 & 0.78 & 0.75 \\ \mathrm{Bi} & 4.40 & 0.78 & 0.83 \\ \mathrm{Cu} & 4.53 & 0.82 & 0.80 \\ \mathrm{Ni} & 4.73 & 0.83 & 0.84 \\ \mathrm{Au} & 4.75 & 0.86 & 0.83 \\ \mathrm{Pd} & 4.80 & 0.86 & 0.86 \\ \mathrm{Pt} & 5.30 & 0.89 & 0.89\end{array}$


On figure $1 \varphi_{\mathrm{B} n}(P)$ has been plotted as a function of $\varphi_{\mathrm{m}}$. It appears that the barrier height shows a linear dependence upon the metal work function. By means

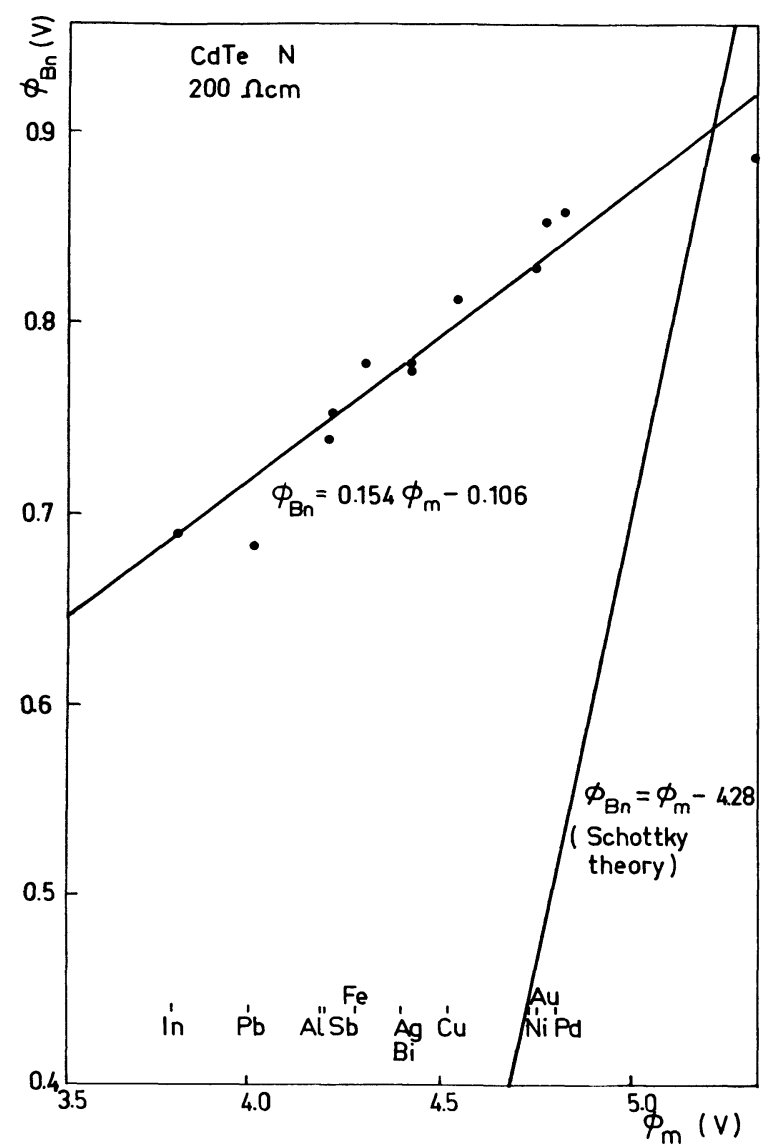

Fig. 1. - Plot of barrier heigh vs. metal work function as determined from photoresponse measurements.

of a least square method calculation the following relation has been computed :

$$
\varphi_{\mathrm{B} n}(P)=0.154 \varphi_{\mathrm{m}}-0.106 .
$$

This relation is far away from the simple Schottky theory which gives for cadmium telluride :

$$
\varphi_{\mathrm{B} n}=\varphi_{\mathrm{m}}-4.28 \text {. }
$$

The low slope $\gamma$ of the straight line of eq. (1) is an indication of strong influence of surface states whose density $D_{\mathrm{S}}$ can be calculated if one assumes that the Cowley and Sze theory [5] applies by using the relation :

$$
D_{\mathrm{S}}=\frac{1-\gamma}{q \delta \gamma} \varepsilon_{\mathrm{i}}
$$

where $q$ is the electronic charge, $\delta$ the interfacial layer thickness and $\varepsilon_{\mathrm{i}}$ the interfacial dielectric constant.

Taking common values such as $\delta=50 \AA$ and $\varepsilon_{\mathrm{i}}=4 \varepsilon_{j}$ leads to $D_{\mathrm{s}} \simeq 10^{13} \mathrm{~cm}^{-2}$. This large density of surface states could be related to the presence at the surface of the samples of an increased concentration of cadmium, as shown on figure 2 where cadmium and tellurium profiles close to the surface of etched cadmium telluride have been measured by SIMS analysis. This results is agreement with the assumptions of Akobirova et al. [6]. Further, we have to point out the presence of bromine in this region.

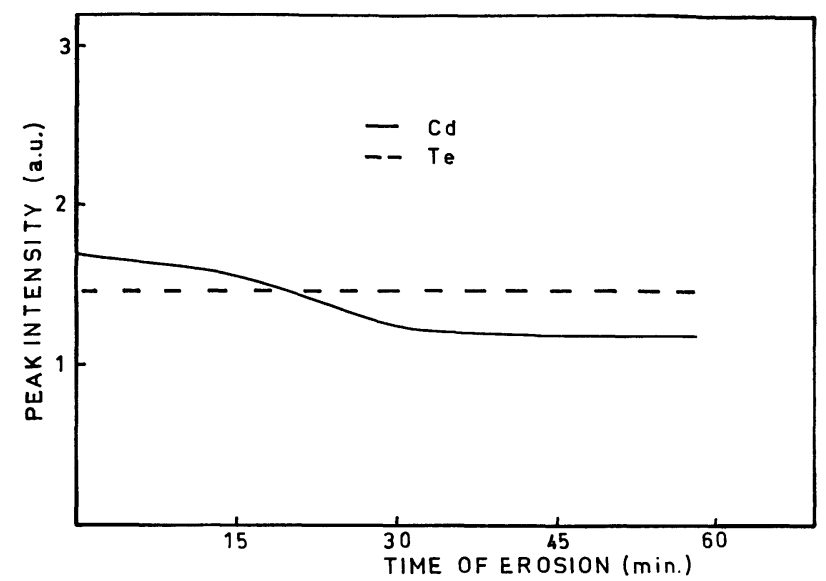

FIG. 2. - Sims analysis of $\mathrm{Cd}$ and $\mathrm{Te}$ at the surface of chemically etched cadmium telluride.

From table I it is seen that rather large discrepancies arise in the photoelectric and forward current determination of the barrier height in the case of the metals with the lower work functions i. e. up to bismuth. For this metals the saturation current is lower than expected and then the barrier height is larger.

In order to get informations on the formation of the barrier the photovoltage and the forward currentvoltage characteristic have been studied under vacuum immediately after the metal deposition and as a function of time after the samples were removed from vacuum. Contrarily to the case of silicon [7] the gold barrier on $\mathbf{N}$ type cadmium telluride is formed immediately after the gold evaporation. The samples show a typical diode behaviour with forward and reverse characteristics. As shown on figure 3, under vacuum (time zero) the open circuit voltage $V_{\text {oc }}$ is $330 \mathrm{mV}$. This voltage increases as soon as the sample is put into air and it reaches a saturation value of $470 \mathrm{mV}$ after about two hours. For the silicon case, in the same experimental conditions, the $V_{\text {oc }}$ value under vacuum was $30 \mathrm{mV}$ and the saturation $(280 \mathrm{mV})$ occured after more than 20 hours. In order to determine if a change in gold-CdTe barrier height occurs in air we have studied the time dependence of the forward $I-V$ characteristic. The main change in this characteristic arises from the value of $n$ (Fig. 3) while the saturation current and then $\varphi_{\mathrm{B} n}$, remains pratically the same. For a Schottky barrier the photovoltage is given by :

$$
V_{\mathrm{oc}}=n\left[\varphi_{\mathrm{B} n}+\frac{k T}{q} \ln \frac{I_{\mathrm{p}}}{S A^{* *} T^{2}}\right]
$$

where $I_{\mathrm{p}}$ is the photogenerated current, $S$ the active area of the device, $T$ the temperature and $A^{* *}$ the effective Richardson constant. The insert of figure 3 where $V_{\text {oc }}$ 


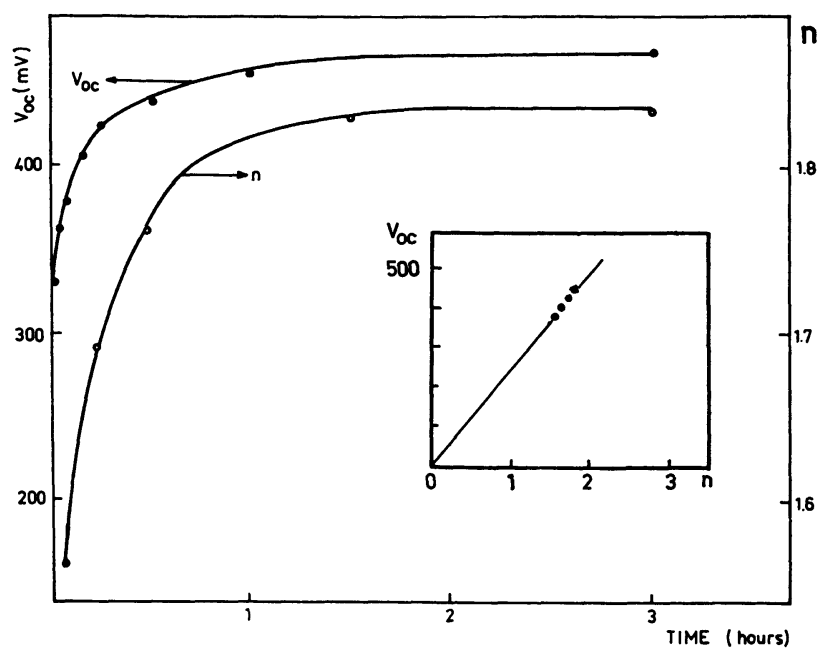

Fig. 3. - Time dependence of photovoltage and diode quality factor in air.

has been plotted as a function of $n$ shows the good linear dependence of the experimental values of $V_{o c}$ upon $n$ while $\varphi_{B n}$ remains constant.

4. Application to solar cells. - On figure 4 has been plotted the maximum theoretical efficiency attainable under AMO conditions for Schottky barriers on silicon and cadmium telluride as a function of barrier height and different temperatures. At $300 \mathrm{~K}$ pratically the same efficiency is obtained for a $0.8 \mathrm{eV}$ barrier on silicon and a $0.9 \mathrm{eV}$ barrier on cad-

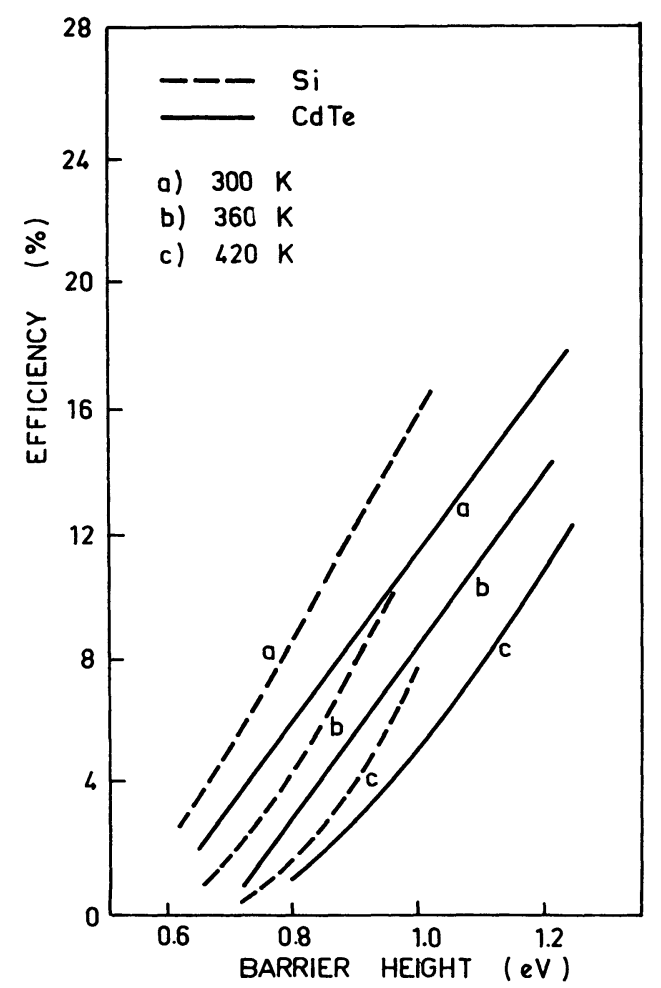

Fig. 4. - Theoretical efficiency of Schottky solar cells on silicon and cadmium telluride as a function of barrier height and temperature. mium telluride. When the temperature increases, as it is well known, the situation becomes more favourable to CdTe due to its larger bandgap. In terms of open circuit voltage higher values will be delivered by CdTe solar cells due to the lower saturation current of the diodes. However, on the other hand the photogenerated current will be lower. On figure 5 we have

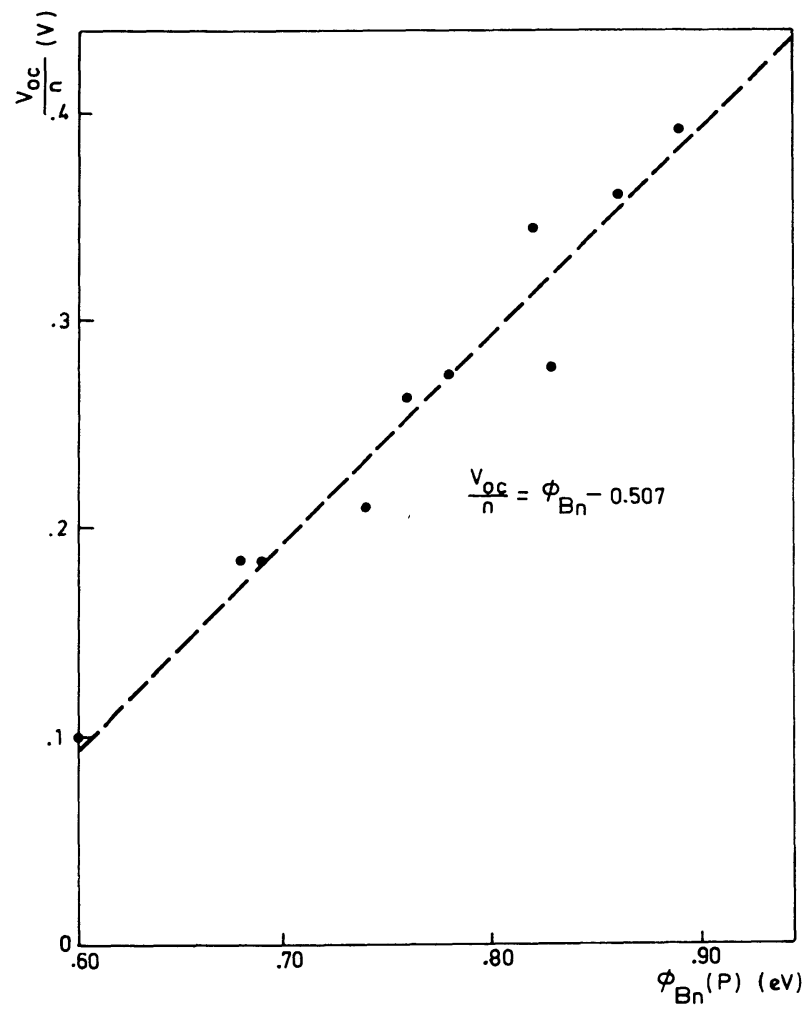

Fig. 5. - Plot of $V_{\mathrm{oc}} / \boldsymbol{n}$ as a function of barrier height for CdTe Schottky solar cells.

plotted $V_{\mathrm{oc}} / n$ as a function of the barrier height $\varphi_{\mathrm{B} n}$. The experimental measurements are in good agreement with eq. (4) where the term $\left(\ln I_{\mathrm{p}} / S A^{* *} T^{2}\right)$ as calculated from the experimental conditions has the value -0.51 . The value of $V_{\text {oc }}$ strongly depends upon the quality factor $n$ and then upon the surface conditions before the realization of the device. For platinum barriers on $\mathrm{N}$ type cadmium telluride open circuit voltages up to $690 \mathrm{mV}$ have been measured.

5. Conclusion. - The barrier height value of various metals deposited on low resistivity etched $\mathrm{N}$ type cadmium telluride have been determined. The results show a linear dependence of $\varphi_{\mathrm{B} n}$ upon $\varphi_{\mathrm{m}}$ and a strong influence of surface states which could result from an oxidation of the surface and the formation of a $\mathrm{CdO}$ layer or from the presence of residual bromine. Barrier heights up to $0.90 \mathrm{eV}$ have been measured, resulting, in the case of applications to solar cells, in open circuit voltage close to $0.7 \mathrm{~V}$. It can be noticed at this time that higher barriers and then higher $V_{\mathrm{oc}}$ should be obtained by the use on cadmium telluride of MIS structures. 


\section{References}

[1] Mead, C. A. and Sprtzer, W., Phys. Rev. 134A (1964) 713.

[2] Parker, G. H. and Mead, C. A., Phys. Rev. 184 (1919) 780.

[3] Wald, F. V., Bell, R. O. and Seneze, H. B., Cadmium telluride detectors. Third Int. Tech. Report Contact N AT-(11-1)-3545 for US Atomic Energy Commission Tyco Laboratories Inc Sept 1973.
[4] Cornet, A., Siffert, P. and Coche, A., J. Crystal Growth 7 (1970) 329.

[5] Cowley, A. M. and Sze, S. M., J. Appl. Phys. 36 (1965) 342. [6] Akobirova, A. T., Maslova, L. V., Matveev, O. A. and Khusainov, R. Kh., Sov. Phys. Semicond. 8 (1975) 1103.

[7] RouilLy, D., Thesis Faculté des Sciences Strasbourg 1968. 